\title{
A Comparison of Maslow's Theory of Hierarchy of Needs with the Pancha Kosha Theory of Upanishads
}

Anuradha Sathiyaseelan*and Sathiyaseelan $\mathrm{B}^{\dagger}$

\section{Abstract}

There is a growing recognition that reductionist and mechanistic worldview that we hold of human motivation needs to be revised and transformed. Many attempts have been made in this direction including a more humanistic approach. In the Western world, Maslow's needs hierarchy was a first such attempt. However, not many attempts have been made to expand further the concept of self-actualization proposed by Maslow. On the other hand, there was a criticism of his approach as not being rooted in research and the real world. In this article, the authors attempt to explore the similarities between the needs hierarchy as proposed by Maslow $(1943,1954)$ and the model of 'Pancha Kosha' or 'five sheaths' theory as presented in the Taittriya Upanishad.

Keywords: Humanistic psychology, motivation, Taittriya Upanishad, Five Sheaths Theory, Pancha Kosha Model

* Department of Psychology, Christ University, Bengaluru, India; anuradha.sathiyaseelan@christuniversity.in

† Institute of Management, Christ University Bengaluru, India; sathiyaseelan.b@christuniversity.in 


\section{Humanism in the Upanishads and Maslow's hierarchy of needs theory}

Humanistic approaches in the Western world, perceive humans as basically positive creatures who develop constructively, given the right conditions (Moss, 2001). The humanist belief is that humans have a natural tendency to strive for the full development of personhood. This innate endeavour for full development includes not only physical growth but also psychological growth to the full unique potential inherent in the person (Polkinghorne, 2001).

Rogers (1986) says the natural tendency of humans to strive for selfactualization depends on the person-centered approach, which helps the tendency to grow to a full potential level. This directional flow helps the individual to achieve the complex and complete development.

Humanists such as Maslow (1943) emphasised both the scientific and philosophical understanding of human existence. The attempt was to understand the conditions or contexts in which a human could reach the highest level in terms of achievement and potential, and thus efforts were focused on presenting a new and better concept of humanity (Moss, 2001). Maslow's hierarchy of human needs $(1943,1954)$ continues to be one of the most enduring contributions to human motivational psychology. As he describes in his book Motivation and Personality(1954), holism is true and everything in the world is interrelated. The holistic way of thinking is preferred by the people who are trying to be self-actualized, while for others, an atomic way of thinking is the preferred one.

In contrast, the reductionist philosophy advocated by Skinner (1953), argued forcefully that human behaviour was strictly determined by the environment. He stressed that changes in human behaviour depend on the occurrence in his/her physical environment. The reductionist view understands individual behaviour by breaking it into small components, which include genes, brain structure and neurochemicals.

In the Indian 'Hindu' context, a 'holistic' and humanistic approach to human existence is espoused as the 'way of life' (Klostermaier, 2007). Among the Western world theories of human motivation, Maslow's hierarchy of needs is one of the early attempts (Wahaba 60 
\& Bridwell, 1976) at evolving a holistic theory of human motivation. Maslow proposed a holistic approach to personality research (Heylighen, 1992).His inclusion of the need levels of selfactualization and later self-transcendence was a great step forward in taking into account 'intangibles' in human motivation and existence. Viewed from an Upanishadic perspective, all other Western theories fail to explain the cause or reason for human existence and man's constant effort to exceed himself.

The Upanishads perceive the human existence as a structure with a combination of material and spiritual aspects. While the Upanishads are popularly believed to be texts of theology and religion, in essence, they are texts of human psychology and scientific points of view, which can be applied to the fields of mindmachine modelling, physiology, psychology and language comprehension in artificial intelligence.

The Taitriya Upanishad is a Sanskrit text of the Vedic era, and a principal and very early Upanishad believed to be composed in the first millennium, but its chronology is unclear (Phillips, 2009). It focuses on the idea of self-knowledge and asserts that realising it is the highest, empowering, liberating knowledge, and the path to a positive state of living (Deussen, 1897).The Taitriya Upanishad is famous for its Kosha (layered) theory, and it propounds that human beings reach their maximum potential of deep knowledge by learning the right things and unlearning the wrong things. This is one of the earliest known theories in history on the nature of man (Deutsch, 1973; Mead \& Hoeller, 2006).This Upanishad claims that human existence can be understood as concentric levels starting from the outermost level 'annamaya kosha' (physical sheath/layer), which envelops 'pranamaya kosha' (vital energy sheath/layer), which in turn envelops 'manomaya kosha' (mental sheath/layer), inside which is 'vijnanamaya kosha' (intellectual sheath/layer), and finally the 'anandamaya kosha' (blissful sheath/layer) which is the innermost layer (Raju, 1954; Mukherjee, 2011; Deutsch, 1973; Narayanasvami Aiyar 1914).

According to Maslow (1943), all humans have a set of five basic needs that require fulfilment for a person to achieve a deeper understanding and knowledge of existence. These needsphysiological needs, safety needs, belongingness and love needs, 
self-esteem needs and self-actualization-are viewed as components of a hierarchical need system. Maslow conceptualised the hierarchy as invariant and argued that lower a need, the more prepotent it will become if unfulfilled. That is, unless the lower need is satisfied, the higher need will not become satisfied.

\section{Similarities between Maslow's hierarchy of needs and the 'five sheaths' model}

Maslow (1943) treats human motivation as forming a hierarchy. His writings have been interpreted in a hierarchical model. Maslow moves from bottom to upwards on the needs scale. Whereas the Taitriya Upanishad treats human existence as one layer nested within the other.It comes from the top to the bottom, from universal existence to individual existence (Taitriya Upanishad translator SS Sastri). From Maslow's hierarchy theory (1943), it would appear that each higher need arises only after the previous lower one has been fulfilled. On the other hand, the Taitriya Upanishad's point of view is that each layer of human existence or motivation resides within the next level. For instance, the 'Annamaya Kosha' (or 'physical sheath') rests within the 'Pranamaya Kosha (or 'vital energy sheath'), which in turn rests within the 'Manomaya Kosha' (or the 'mental sheath') and so on ( Ollivelle, 1996; Narayanasvami Aiyar 1914)

The outermost layer in the 'five sheaths' theory speaks about how the human body absorbs the essence from the food and water for its development all through the life span - from the womb to the grave. The layer formed from the intake of food, water and air forms the 'Annamaya Kosha' or the physical sheath. With proper diet and proper exercise, the body uses the nutrients for the growth of physical elements. Without these elements focusing would be impossible for attaining greater knowledge.

Maslow says physiological needs are those needs such as air, water, food, and sleep, which are required for sustaining life. If these needs are satisfied, then the individual goes to the next level, that is, safety needs.

Prana is the life force and is part of cosmic life that helps motion or vibration. All the activities of the body and mind take place 
because of Prana. Hence it is called the vital sheath. Wherever Prana is present, growth and development take place. When there is balance in Prana (or vital energy), the body and mind are balanced.

Maslow speaks of the need for a family, employment, health, and other resources as safety needs. But the Pranamaya Kosha speaks of how the vital energy helps in the total health of the individual, leading from sense perception to understanding the thought process.

The point here is that Pranamaya Kosha can be juxtaposed against Maslow's safety needs. The vital energy is responsible for the safety of all the vital organs including mind and the physical actions. And without these, the total health of the individual cannot be achieved.

Manomaya Kosha is the third inner layer responsible for knowledge-seeking related to the mind/thought, characterised by the power to will, the ability to wish, and the striving for prosperity through outward actions on knowledge and beings (Deussen, 1897). The mind is outward looking, seeking to engage with the world and fellow beings, in order to seek knowledge of the world and through it, the knowledge of the self. As Sri Aurobindo (1990) describes, at this level the human beings would be united with other beings by sympathy, love and happiness, and their emotions would be lifted to the perfection of the psychological plane.

Maslow (1954) points out that when both the physiological and the safety needs are well gratified, there will emerge the love and belongingness needs. Now the individual will strive to satisfy these needs.

The Vijnanamaya Kosha is deeper and profound layer of existence than the other sheaths. Vijnana means intellect, the power of judgment and discernment. When this sheath is activated, the individual attains inner perception, purity, self-discipline and will be devoted to ethical thoughts and moral values that are free from instincts. Human beings, when raised to this level,will be a source of profound knowledge and wisdom to others (Deussen, 1897). Hence, we may say that the healthy development of this Kosha leads us towards self-acceptance, which is the core of self-esteem. Onecan also argue that when an individual is self-disciplined, 
devoted and focused, appreciation and recognition will come to him.

According to Maslow (1954), among human beings, the need for appreciation and recognition arises when they are satisfied with the other lower order needs. The satisfaction of self-esteem need leads to feelings of self-confidence, self-worth, strength, capability and adequacy of being that are useful and necessary in the world. At this level, competence, achievement and responsibility come naturally and easily out of one's own true inner nature, or in other words, out of one's real self rather than out of the idealised pseudoself (Horney, 1950).

Anandamaya Kosha is the inner most component in the five sheath model and is characterised by tranquillity, contentedness, love, joy and cheerfulness. The individuals who attain this level realise simultaneously the empirical and the spiritual, the conscious and unconscious, the changing and the eternal, the time and the timeless (Deussen, 1897). The human being who has selfknowledge is well constituted and is full of bliss. He exists in peace both within and without and is in a state of calm and joy. He is free from pride, guilt and craving desires (Deussen, 1897).

According to Maslow (1954), even if all needs are satisfied, one can still experience a new discontentment and restlessness, unless the individual is doing what he individually is capable of. This need called self-actualization refers to the human desire for the highest form self-fulfillment. This need differs from person to person and depends on the nature of the individual. For example, one personmay like to be a good artist; the other may like to be just a good human being. Maslow argues that once the individual attains personal growth and becomes less concerned about the opinion and view of others, he attains the stage of self-actualization, where he is aware of the self, which leads to a state of bliss. 
Table 1: Pancha Kosha vsNeed hierarchy

\begin{tabular}{|c|c|c|c|}
\hline \multicolumn{2}{|c|}{$\begin{array}{c}\text { 'Pancha Kosha' / 'Five sheath' } \\
\text { theory } \\
\text { Human existence can be } \\
\text { understood in terms of five } \\
\text { concentric levels }\end{array}$} & \multicolumn{2}{|c|}{$\begin{array}{l}\text { Maslow's hierarchy of needs } \\
\text { Humans have five basic needs, } \\
\text { and these are interlinked and } \\
\text { arranged in a hierarchy of } \\
\text { prepotency. }\end{array}$} \\
\hline 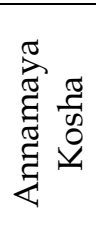 & $\begin{array}{l}\text { The Physical sheath is a } \\
\text { result of intake of food, } \\
\text { water, air, etc. }\end{array}$ & 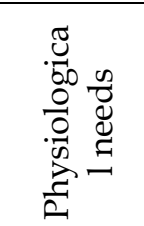 & $\begin{array}{l}\text { Need for food, water, } \\
\text { air, sleep and sex that } \\
\text { are necessary for the } \\
\text { sustenance of life. }\end{array}$ \\
\hline 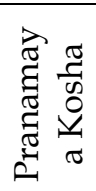 & $\begin{array}{l}\text { The Vital energy sheath } \\
\text { that controls the life } \\
\text { energy. }\end{array}$ & 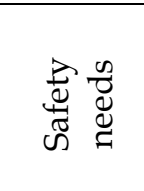 & $\begin{array}{l}\text { Need for a secure } \\
\text { employment, family, } \\
\text { health and other } \\
\text { resources. }\end{array}$ \\
\hline 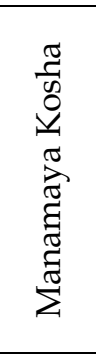 & $\begin{array}{l}\text { The mental sheath } \\
\text { knowledge seeking related } \\
\text { to the mind/thought, } \\
\text { characterised by the power } \\
\text { to will, the ability to wish, } \\
\text { and the striving for } \\
\text { prosperity through } \\
\text { outward actions }\end{array}$ & 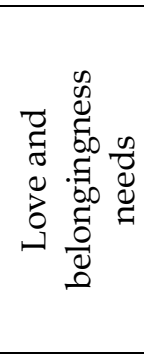 & $\begin{array}{l}\text { When physiological } \\
\text { and the safety needs } \\
\text { are well gratified, } \\
\text { there will emerge the } \\
\text { love and } \\
\text { belongingness needs. } \\
\text { The individual will } \\
\text { strive to achieve them. }\end{array}$ \\
\hline 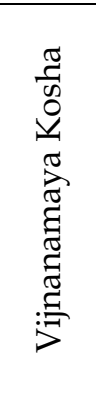 & $\begin{array}{l}\text { The Intellectual sheath - } \\
\text { individual attains inner } \\
\text { perception, purity, self- } \\
\text { discipline and will be } \\
\text { devoted to ethical thoughts } \\
\text { and moral values that are } \\
\text { free from instinct }\end{array}$ & 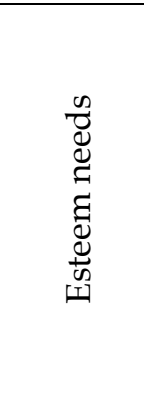 & $\begin{array}{l}\text { The satisfaction of } \\
\text { self-esteem need leads } \\
\text { to feelings of self- } \\
\text { confidence, self- } \\
\text { worth, strength, } \\
\text { capability and } \\
\text { adequacy of being } \\
\text { useful and necessary } \\
\text { to the world }\end{array}$ \\
\hline 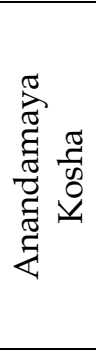 & $\begin{array}{l}\text { The Blissful sheath - } \\
\text { Realisation of the empirical } \\
\text { and the spiritual, the } \\
\text { conscious and unconscious, } \\
\text { the changing and the } \\
\text { eternal, the time and the } \\
\text { timeless }\end{array}$ & 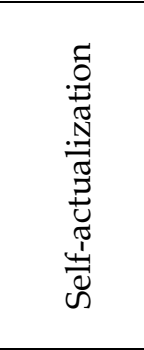 & $\begin{array}{l}\text { Self-actualization } \\
\text { refers to man's desire } \\
\text { for self-fulfillment, } \\
\text { namely, the tendency } \\
\text { to become what he } \\
\text { potentially can } \\
\text { become, that is, } \\
\text { become actualized. }\end{array}$ \\
\hline
\end{tabular}




\section{Conclusion}

The objective of the present article is to compare the Western theories of motivation with the Indian theory of 'five sheath model' as elaborated in the Taittriya Upanishad. Among the Western theories of human motivation, Maslow's needs hierarchy is probably the one theory that attempts to avoid a reductionist approach and takes a holistic approach to explain human motivation as the need to achieve the highest potential. Therefore, we feel that Maslow's needs hierarchy is an appropriate humanist model that can be compared with the 'five sheaths' (Pancha Kosha) theory, which explores the purpose of human existence from a'very high level' perspective.

It is hoped that the paper will stimulate interest among the contemporary academicians to attempt comparative studies of Western and Eastern views about human nature, especially the study of motivation and the Self-concept. Discussion and debate in this field will enrich both Eastern and Western thinkers.

Spirituality is a beautiful word with a lot of meaning. People who engage in spiritual practices experience a fulfilment similar to transcendence (Barrett N.F 2011). In this fast moving world, each human being is searching for fulfilment and peace in life. Revisiting and understanding Indian literature and applying the principles enshrined in it in the life of the people of modern times will be a great help in understanding the human psyche.

Self-motivation and self-fulfillment can lead to balanced life marked by peace and happiness. The researchers encourage further work in this area to decipher how each "Kosha" functions and how it leads to the next level. The other hope is to link it with the practice of mindfulness meditation and seven chakra meditations.

\section{References}

Aurobindo, S. (1990). The synthesis of yoga. Lotus Press.

Barrett, N. F. (2011). Wuwei and flow: Comparative reflections on spirituality, transcendence, and skill in the Zhuangzi. Philosophy East and West, 61(4), 679-706. 
Deussen, P. (1897). Sixty Upanishads of the Veda.

Deutsch, E. (1973). Advaita Vedanta: A Philosophical Reconstruction. University of Hawaii Press.

Freud, S., \& Bonaparte, P. M. (1954). The origins of psychoanalysis (Vol. 216). London: Imago.

Heylighen, F. (1992). A cognitive-systemic reconstruction of Maslow's theory of self-actualization. Behavioral Science, 37(1), 39-58.

Horney, K. (1950). Neurosis and human growth, New York (WW Norton) 1950.

Klostermaier, K. K. (2007). A survey of Hinduism. SUNY Press.

Klostermaier, K. K. (2010). Vidyaranya Swami's" pañca viveka" and Thomas Aquinas'" quinqueviae" in the Light of Today's Science. Journal of Hindu-Christian Studies, 23(1), 9.

Larson, G. J. (2001). Classical Sāṃkhya: An interpretation of its history and meaning. Motilal Banarsidass Publ.

Maslow, A. H. (1943). "A theory of human motivation". Psychological Review. 50 (4): 370-396. doi:10.1037/h0054346.

Maslow, A. H. (1954). Motivation and personality. New York: Harper.

Mead, G. R. S., \& Hoeller, S. A. (2006). The Hymns of Hermes. Weiser Books.

Moss, D. (2001). The roots and genealogy of humanistic psychology. The handbook of humanistic psychology: Leading edges in theory, research, and practice, 5-20.

Mukherjee, S. (2011). Indian Management Philosophy. In Handbook of Spirituality and Business (pp. 80-87). Palgrave Macmillan UK.

Müller, F. M. (1879). Taittiriya Upanishad. The sacred books of the East (Vol. 15). Oxford University Press.

Narayanasvami Aiyar. K. (1914). Thirty Minor Upanishad. Madras Patrick Olivelle (1996), The Early Upanishads: Annotated Text \& Translation, Oxford University Press, ISBN 978-0195124354, Introduction Chapter 
Phillips, S. (2009). Yoga, karma, and rebirth: a brief history and philosophy. Columbia University Press.

Polkinghorne, D. E. (2001). The self and humanistic psychology. The handbook of humanistic psychology: Leading edges in theory, research and practice, 81-99.

Raju, P. T. (1954). The concept of the spiritual in Indian thought. Philosophy East and West, 4(3), 195-213.

Rogers, C. R. (1986). A client-centered/person-centered approach to therapy. In I. Kutash \& A. Wolf (Eds.), Psychotherapist's Casebook (pp. 197-208). San Francisco: Jossey-Bass.

Sastri, S. S. (1901). Aitareya and Taittiriya Upanishads.

Skinner, B. F. (1953). Science and human behaviour. Simon and Schuster.

Wahba, M. A., \& Bridwell, L. G. (1976). Maslow reconsidered: A review of research on the need hierarchy theory. Organisational behaviour and human performance, 15(2), 212-240. 